\author{
MARIUSZ ZAJĄCZKOWSKI \\ https://orcid.org/0000-0002-3964-8109 \\ Instytut Studiów Politycznych PAN, Warszawa \\ Instytut Pamięci Narodowej, Lublin
}

\title{
WYWAŻANIE OTWARTYCH DRZWI? DYWAGACJE BOGDANA HUKA O WSPÓLNEJ POLSKO-UKRAIŃSKIEJ WALCE Z REŻIMEM KOMUNISTYCZNYM W POLSCE LUBELSKIEJ*
}

\begin{abstract}
Abstrakt: Lata 1945-1947 to burzliwy okres w dziejach południowo-wschodnich ziem dzisiejszej Polski. Tereny te były wówczas objęte działalnością polityczną i zbrojną antykomunistycznych konspiracji polskiej i ukraińskiej. Zwalczały je, choć w niejednakowym stopniu, władze ówczesnej Polski i wspierający je sowiecki aparat represji oraz wojsko. Podziemne poakowskie z jednej strony i banderowskie z drugiej zawarły tu wiosną 1945 r. rozejm, przestrzegany do akcji „Wisła” w 1947 r.
\end{abstract}

Słowa kluczowe: Polska „lubelska” 19441947, podziemie polskie (AK, DSZ, WiN), podziemie ukraińskie (OUN-B, UPA), konflikt narodowościowy, porozumienie polsko-ukraińskie.
Abstract: The years 1945-1947 was a stormy period in the history of the south-eastern lands of today's Poland. At that time, the territories were under political and armed activity of anti-communist Polish and Ukrainian undergrounds. They were fought against, albeit to a different extent, by the contemporary Polish authorities and supporting them Soviet apparatus of repression and the army. It was there that in the spring of 1945 the post-Home Army Underground on the one side, and Banderites Underground on the other agreed on a truce, respected to the Vistula Operation in 1947.

Keywords: Lublin's Poland 1944-1947, Polish Underground (Home Army, Armed Forces Delegation for Poland, Freedom and Independence), Ukrainian Underground (Organization of Ukrainian Nationalists led by Stepan Bandera and the Ukrainian Insurgent Army), nationality conflict, Polish-Ukrainian agreement.

* UPA i WiN w walce z totalitaryzmem 1945-1947. Dokumenty. Wspomnienia, red. Bogdan Huk, Stowarzyszenie Ukraińskie Dziedzictwo, Przemyśl 2018, ss. 753. 
W rekomendacji umieszczonej przez wydawcę na czwartej stronie okładki recenzowanej książki czytamy:

ukazuje [ona] bardzo ważny, nieantagonistyczny fragment przeszłości Ukraińców i Polaków w powojennej Rzeczypospolitej Polskiej. [--] Bezcenny materiał archiwalny zawarty w tym wydaniu jest owocem wielu lat pracy jego redaktora, Bogdana Huka. [--] Wydanie jest unikalne pod względem doboru, treści oraz ilości opublikowanych dokumentów (59) i wspomnień (15). Wzbogaca dotychczasowy stan wiedzy i pozwala dyskutować z obecną polityką historyczną w Polsce i w Ukrainie.

Z pewnością za walor poznawczy pracy Huka należy uznać zaprezentowanie $\mathrm{w}$ tłumaczeniu na język polski dokumentów Organizacji Ukraińskich Nacjonalistów Stepana Bandery (OUN-B) i Ukraińskiej Armii Powstańczej (UPA) dotyczących kontaktów z polskim podziemiem antykomunistycznym wywodzącym się z Armii Krajowej (AK) - Delegaturą Sił Zbrojnych na Kraj (DSZ), następnie Zrzeszeniem Wolność i Niezawisłość (WiN) na wschodniej Lubelszczyźnie w latach 1945-1947, w tym głównie wspólnej akcji zbrojnej w miasteczku Hrubieszów z 27 na 28 maja 1946 r. Choć w znakomitej większości wspomniane dokumenty były publikowane wcześniej w języku ukraińskim ${ }^{1}$, to do tej pory nie były one znane szerzej polskiemu czytelnikowi.

To samo można powiedzieć, choć nie w odniesieniu do porozumień polsko-ukraińskich, co raczej do dziejów OUN-B i UPA na wschodniej Lubelszczyźnie w końcowym okresie okupacji niemieckiej i we wczesnych latach powojennych, o przetłumaczonych na język polski, chociaż nie w całości, dwóch obszernych sprawozdaniach kierownika (prowidnyka) Okręgu III OUN-B Jewhena Sztendery „Prirwy” [Êvgen Štendera „Prirva”]. Zostały one sporządzone w Monachium w sierpniu i wrześniu 1948 r., po przedostaniu się Sztendery z Polski do amerykańskiej strefy okupacyjnej w zachodnich Niemczech ${ }^{2}$.

Cenne dla badaczy zajmujących się m.in. zagadnieniem porozumień polsko-ukraińskich w latach 1945-1947 są również fragmenty rozmów przeprowadzonych przez Huka z byłym członkiem podziemia ukraińskiego, wspomnianym już Sztenderą ${ }^{3}$, oraz z Marianem Gołębiewskim

${ }^{1}$ Zob. Litopis UPA, t. 39: Taktičnij vidtinok UPA 28-j „Daniliv”": Cholmŝina ì Pìdlâššâ (Dokumenti ì materâli), red. P. Potǐcnij, Toronto-L'vìv 2003.

2 Sprawozdanie Eugeniusza Sztendery „Prirwy” o przedostaniu się z Kraju Zakerzońskiego do Niemiec Zachodnich, Monachium, 14 sierpień 1948, w: UPA i WiN, s. 388-409; Sprawozdanie Eugeniusza Sztendery o UPA na Chełmszczyźnie i Podlasiu i na terenie 28. Odcinka Taktycznego „Danyliw” w latach 1943-1948, Monachium, wrzesień 1948, w: ibidem, s. 410-438.

${ }_{3}$ Rozmowa z Eugeniuszem Sztendera, w: ibidem, s. 3-69. 
„Irką", „Sterem”, oficerem AK/DSZ i WiN ${ }^{4}$ W przypadku pierwszego z rozmówców interesujące są przede wszystkim informacje dotyczące najmniej znanego okresu w jego życiorysie, czyli działalności w strukturach OUN-B na terenie Lubaczowskiego od zimy 1944/1945 do wiosny 1945 r. W odniesieniu do drugiego zaś informacje na temat różnic między AK/DSZ a Narodowymi Siłami Zbrojnymi (NSZ) w podejściu do kwestii ukraińskiej i zawarcia wiosną 1945 r. przez AK/DSZ rozejmu z podziemiem banderowskim na wschodniej Lubelszczyźnie; ich następstwem były nieporozumienia i napięcia między obu polskimi organizacjami niepodległościowymi na tym terenie. Badaczy zainteresuje ponadto stosunek Gołębiewskiego do zbrodni popełnionej przez NSZ na ukraińskich mieszkańcach wsi Wierzchowiny w powiecie krasnostawskim 6 czerwca 1945 r.

Wartością dodaną książki jest również to, że jej Autor - jak się wydaje - właściwie ustalił, którym w istocie z trzech delegatów ukraińskich widniejących na fotografiach dokumentujących spotkanie z 21 maja 1945 r. w przysiółku Żar w pobliżu Lublińca Nowego w powiecie lubaczowskim był Jurij Łopatynśkyj „Szejk” [Ûrìj Lopatins'kij, „Šejk”].

Recenzowana praca ma niestety więcej mankamentów niż stron pozytywnych. Najsłabszą jej częścią jest wprowadzenie (wstęp) do zagadnienia pt. „Między walką a porozumieniem”. Wbrew ogólnie przyjętym standardom dla publikacji naukowych, w tym tomów źródeł, nie znajdziemy w nim przeglądu dotychczasowej literatury przedmiotu, dodajmy dość bogatej, czy chociażby podstawowych informacji na temat aktualnego stanu badań dotyczącego problematyki porozumień polsko-ukraińskich z lat 1945-19475. Trudno bowiem za takie uznać przemyślenia Autora, w których przeważa jednostronna narracja narodowa, znana z wcześniejszych jego publikacji ${ }^{6}$. Zawierają one tezy, pod którymi rzetelnemu badaczowi

${ }^{4}$ Rozmowa z Marianem Gołębiewskim, w: ibidem, s. 71-102.

5 Zob. np. G. Motyka, R. Wnuk, Pany i rezuny. Wspótpraca AK-WiN i UPA 1945-1947, Warszawa 1997; R. Wnuk, Lubelski Okręg AK DSZ i WiN 1944-1947, Warszawa 2000; J. Kopiński, Relacje WiN-UPA w Inspektoracie WiN Biała Podlaska w latach 1945-1947, „Zeszyty Historyczne WiN-u" 1996, 9, s. 85-90; G. Ostasz, Nad protokołem rozmów WiN-UPA z 18 maja 1946 roku, „Zeszyty Historyczne WiN-u” 2000, 14, s. 159-164; M. Zajączkowski, Drogi do porozumienia między polskim i ukraińskim podziemiem niepodległościowym w latach 1945-1947, w: Od zniewolenia do wolności. Studia historyczne, red. A.F. Baran, Warszawa-Białystok 2009. Z nowszych publikacji na ten temat zob.: M. Moszkowicz, Gdzie w maju 1945 r. kierownictwo Inspektoratu AK-DSZ Zamość prowadziło rozmowy i zawarło porozumienie z OUN-B i UPA?, „Cieszanowskie Zeszyty Regionalne” 2012, 5, s. 71-84; M. Zajączkowski, Pod znakiem króla Daniela. OUN-B i UPA na Lubelszczyźnie 1944-1950, Lublin-Warszawa 2016; J. Dudek, Marian Gołębiewski (1911-1996) - żołnierz, opozycjonista, emigrant, Lublin 2016.

${ }^{6}$ „W 1938 roku rząd polski zapoczątkował ostatnią fazę administracyjnego ludobójstwa na ludności ukraińskiej, które nie doszło do skutku ze względu na wybuch wojny", 
W istocie nie sposób się podpisać. W dodatku mające bardzo luźny związek z głównym tematem pracy, mocno dyskusyjne i obarczone dość licznymi błędami rzeczowymi. A niekiedy wręcz ocierające się o absurd.

Do tej kategorii na przykład należy zaliczyć następujące stwierdzenie Autora: „w 1943 r. OUN przekroczyła autorytarny Rubikon - zaczęła się demokratyzować. [--] Pociągnęło to za sobą ciąg ważkich następstw: powstrzymanie bandyckiego chłopstwa na Wołyniu, wciąganie go do zorganizowanej działalności, powstanie UPA i opanowanie rebelii wołyńskiej, a w końcu przejście do negocjacji z rządem RP”. Albo pogląd, że konflikt polsko-ukraiński w świetle decyzji, jakie zapadły na III Konferencji OUN-B (17-23 II 1943), a następnie podczas III Zjazdu OUN-B (21-25 VIII 1943) jakoby „zaczął toczyć się na linii autorytaryzm RP - demokratyzm OUN”. Podobnie przekonanie: „O ile RP zyskuje w zestawieniu z totalitaryzmem Stalina, to traci na porównaniu z demokratycznym programem i praktyką OUN zainicjowaną w 1943 r.”7 lub: „Na początku 1943 r. na Wołyniu wybuchła nie ounowska rewolucja, a chłopska guerilla". W końcu pogląd, według którego: „Cele polityczne OUN były szersze, niż wyobrażała to sobie AK czy Delegatura Rządu na Kraj. Wyganianie ludności określanej jako polska nie było jednym z nich. Chodziło bowiem o to, aby ludność ta zmieniła lojalność i zamiast być fundamentem okupacji RP stała się fundamentem ukraińsko-polskiego sojuszu antykomunistycznego" 9 . Zapoczątkowanie procesu „demokratyzacji” przez OUN-B w 1943 r. było w istocie jedynie zabiegiem taktycznym wobec możliwego scenariusza zwycięstwa aliantów zachodnich w wojnie z III Rzeszą. W obawie przed kojarzeniem banderowców z faszyzmem i traktowaniem ich jako sojuszników Niemiec podjęto decyzję o odejściu od dotychczasowej ideologii głównie w warstwie symbolicznej ${ }^{10}$. Niezależnie od bardzo wątpliwej tezy o spontanicznej chłopskiej rebelii na Wołyniu, doprawdy trudno uznać za przejaw „demokratyzacji” OUN-B mord dokonany na kilkudziesięciu tysiącach wołyńskich Polaków na przestrzeni roku, od lutego 1943 do lutego $1944 \mathrm{r}$.

Za to że jesteś Ukraińcem... Wspomnienia z lat 1944-1947, oprac. B. Huk, Koszalin-Warszawa-Przemyśl 2012, s. 17-18, przyp. 4; „Atak oddziałów AK na Sahryń i 10 innych wsi ukraińskich był jedną z największych zbrodni dokonanych przez jakiekolwiek oddziały partyzanckie przeciw ludności cywilnej w całej Europie podczas II wojny światowej", ibidem, s. 33, przyp. 11.

${ }^{7}$ UPA $i$ WiN, s. xx.

8 Ibidem, s. xxi.

9 Ibidem, s. xxiii.

10 Zob. np. G. Motyka, Ukraińska partyzantka 1942-1960. Działalność Organizacji Ukraińskich Nacjonalistów i Ukraińskiej Powstańczej Armii, Warszawa 2006, s. 115-118, 122-125. 
Za osobliwe uznać należy również inne konstatacje Autora. Na przykład:

Najbardziej dalekosiężnym pozytywnym pokłosiem zwycięskiego ataku UPA w dniu 9 kwietnia 1944 r. przeciwko AK pod Posadowem [na Chełmszczyźnie] była możliwość późniejszego porozumienia z 21 maja 1945 r. między UPA i WiN [winno być: AK/DSZ, gdyż Zrzeszenie WiN nie istniało jeszcze w tym czasie - M.Z.]: gdyby UPA zachłysnęła się zwycięstwem i ruszyła na polskie wsi, porozumienie to, w tym wspólny atak UPA i WiN [na] Hrubieszów, nie byłby możliwy. Jednak dowództwo UPA nie pozwoliło swym żołnierzom wytworzyć stanu, który uniemożliwiłby potem stronie przeciwnej porozumienie $\mathrm{z}$ dotychczasowym wrogiem ${ }^{11}$.

Należy podkreślić, że Autor odnosi się do kulminacyjnej fazy akcji antypolskiej na Chełmszczyźnie, która bynajmniej nie zakończyła się na tym terenie 9 kwietnia 1944 r., a raczej przybrała wówczas na sile. Wystarczy wspomnieć, że po tej dacie na przestrzeni kolejnych ponad dwóch miesięcy tylko na terenie południowych gmin powiatu zamojskiego w dystrykcie lubelskim Generalnego Gubernatorstwa (GG) partyzanci UNS (Ukraińska Samoobrona Ludowa)/UPA wymordowali około 600-650 polskich chłopów (m.in. w Kolonii i folwarku Plebanka, Chodywańcach, Nabróżu, Jędrzejówce, Lipsku, w końcu w czasie napadu na pociąg pod Zatylem na odcinku kolejowym Bełżec-Rawa Ruska), z czego ponad 400 osób w maju 1944 r. Ponadto tylko w kwietniu tego roku napady na ludność polską miały miejsce również w ponad 20 miejscowościach położonych na pograniczu powiatów rawskiego (dystrykt Galicja) z powiatami hrubieszowskim i zamojskim (dystrykt Lublin). W ich wyniku z rąk ukraińskich partyzantów w pojedynczych i zbiorowych mordach życie straciło do 350 osób ${ }^{12}$.

Huk, pisząc o przyczynach wystąpień antyukraińskich AK i Batalionów Chłopskich (BCh) w Hrubieszowskiem z marca 1944 r., konstatuje z przekonaniem graniczącym z pewnością: „historiografia nie wypracowała przekonującej opowieści na temat przyczyn mordu 10-11 marca 1944 r. Według mnie zbrodnia ta stanowi «ukraiński współczynnik» umowy scaleniowej AK z Narodową Organizacją Wojskową w Lubelskiem. Umowę zawarto 7 marca 1944 r., a mord nastąpił 10-11 marca 1944 r."13.

${ }^{11}$ UPA $i$ WiN, s. xxvii-xxviii.

12 Zob. np. G. Motyka, Tak było w Bieszczadach. Walki polsko-ukraińskie 1943-1948, Warszawa 1999; M. Zajączkowski, Ukraińskie podziemie na Lubelszczyźnie w okresie okupacji niemieckiej 1939-1944, Lublin-Warszawa 2015.

${ }^{13}$ UPA $i$ WiN, s. xxviii. 
Nie bardzo wiadomo, co Autor miał na myśli pisząc te słowa. Wydaje się, że chyba zgłoszenie 7 marca 1944 r. przez Tymczasową Narodową Radą Polityczną gotowości podporządkowania się nie Narodowej Organizacji Wojskowej (NOW), lecz NSZ, i nie dowództwu Okręgu Lubelskiego, a Komendzie Głównej (KG) AK. Faktycznie owo podporządkowanie z wiosny 1944 r. ograniczyło się jedynie do środowiska konspiratorów NSZ wywodzącego się z tej części NOW, która w 1942 r. odmówiła scalenia się z AK i przyłączyła się do Związku Jaszczurczego (ZJ) powiązanego ze skrajnie prawicowymi Organizacją Polską i Grupą „Szańca”, wywodzącą się z przedwojennego Obozu Narodowo-Radykalnego „ABC”, tworząc z nimi NSZ. Warto wspomnieć, że z akcji scaleniowej wiosną $1944 \mathrm{r}$. wyłamało się NSZ ZJ. Nawiasem mówiąc, scalenie nie nastąpiło z chwilą podpisania umowy, jak sugeruje Huk, lecz był to proces, który rozpoczął się nie wcześniej niż w połowie kwietnia i nie później niż pod koniec maja 1944 r. Dopiero bowiem 15 kwietnia tego roku został wydany przez KG NSZ „Rozkaz wstępny do akcji scaleniowej NSZ w ramach AK”, który 25 maja tego roku w osobnym rozkazie podał do wiadomości komendant Lubelskiego Okręgu NSZ, mjr Zygmunt Broniewski „Bogucki”. Zatem wspomniana akcja scaleniowa nie miała żadnego związku ani też wpływu na przebieg „rewolucji hrubieszowskiej” AK i BCh z marca 1944 r. Niezależnie od tego faktu należy podkreślić, że wiosną 1944 r. struktury NSZ ZJ nie istniały na Zamojszczyźnie, a NSZ NOW były słabe ${ }^{14}$. Z tego powodu polscy nacjonaliści nie mogli odegrać znaczącej roli w konflikcie z Ukraińcami na tym terenie.

Jak wspomniano, z punktu widzenia badaczy problemu prezentowane w pracy Huka dokumenty i wspomnienia, zarówno pod względem doboru, jak i treści nie stanowią novum (poza nielicznymi wyjątkami ${ }^{15}$ ). Być może jest nim zgromadzenie ich wszystkich w jednej publikacji, ale to chyba zbyt mało, aby przesądzać o jej unikalnym charakterze.

${ }^{14}$ M. Zaborski, Okręg Lubelski Narodowych Sił Zbrojnych 1942-1944, w: Narodowe Sity Zbrojne. Materiały z sesji naukowej poświęconej historii Narodowych Sił Zbrojnych, Warszawa 25 października 1992 roku, [red. P. Szucki], Warszawa 1994, s. 195-207, 210-216.

${ }^{15}$ Należą do nich w zasadzie niepublikowane wcześniej wspomnienie i 14 rozmów z byłymi ukraińskimi konspiratorami, w tym Sztenderą (s. 3-69), z czego co najmniej sześć z członkami SB OUN, pięć z członkami terenowych struktur OUN-B, cztery z partyzantami UPA (s. 441-716) oraz jedna rozmowa $z$ byłym przedstawicielem podziemia polskiego, oficerem AK/DSZ i WiN Marianem Gołębiewskim (s. 71-102). Ponadto nieliczne dokumenty, np. jedyny w zbiorze proweniencji sowieckiej (s. 253-258). Nawiasem mówiąc, wybiórczo zaczerpnięte informacje z drugiego dokumentu sowieckiego, lecz bez podania źródła, znajdują się w innym miejscu recenzowanej pracy (s. 442, przyp. 1). Por. Rosyjskie Państwowe Archiwum Wojskowe w Moskwie (dalej: RGWA), f. 38669, op. 1, t. 32, k. 397; M. Zajączkowski, Pod znakiem króla Daniela, s. 147. 
Tym bardziej że były one wcześniej w dużej części publikowane (dokumenty ukraińskie i polskie), jeżeli nie w całości, to przynajmniej we fragmentach. $Z$ całą pewnością znakomita większość, o ile nie wszystkie z zawartych w książce dokumentów, były wykorzystywane we wcześniejszych opracowaniach naukowych. Znamienne, że Autor, korzystając z tych opracowań, w wielu przypadkach nie raczył o tym wspomnieć w przypisach $^{16}$, czyniąc to jedynie sporadycznie ${ }^{17}$. W związku z powyższym duża część ustaleń zawartych w książce nie jest bynajmniej „owocem wielu lat pracy" Huka, lecz wynikiem często wieloletnich badań innych autorów.

Wbrew tytułowi recenzowane opracowanie nie prezentuje $\mathrm{w}$ ujęciu całościowym zagadnienia porozumień polsko-ukraińskich w latach 1945-1947 na południowo-wschodnich ziemiach powojennej Polski. Jego głównym tematem wydaje się być przybliżenie okoliczności wspólnej akcji zbrojnej polskiej i ukraińskiej partyzantki w miasteczku Hrubieszów w nocy z 27 na 28 maja 1946 r. i wyeksponowanie w niej jako kluczowej roli wspomnianego Jewhena Sztendery „Prirwy”; zagadnieniu temu zostały w pełni poświęcone 23, a częściowo pięć z ogółem 59 dokumentów lub ich fragmentów zamieszczonych w pracy. Autor położył nacisk na punkt kulminacyjny polsko-ukraińskiego porozumienia na wschodniej Lubelszczyźnie i to jedynie w wymiarze wojskowym, mimo że obok zbrojnego oporu wobec reżimu komunistycznego zakładało ono przede wszystkim powstrzymanie się przez obie strony od aktów terroru w stosunku do ludności przeciwnika. Porozumienie polsko-ukraińskie na tym terenie przejawiało się również w innych aspektach. Na przykład we współpracy wywiadowczej i na płaszczyźnie propagandy antykomunistycznej. Ale też w postaci przyjaznych gestów, np. życzeń świątecznych i noworocznych od ukraińskich dla polskich konspiratorów, czy po prostu w pozytywnych relacjach między dawnymi znajomymi z lat dzieciństwa lub ławy szkolnej, sąsiadami, których w czasie II wojny światowej podzielił krwawy konflikt narodowościowy ${ }^{18}$.

Za nieuzasadniony zabieg, zważywszy na temat i ramy chronologiczne opracowania, należy uznać pominięcie przez Autora najważniejszych w procesie przechodzenia od konfliktu do porozumienia okoliczności rozmów polsko-ukraińskich w powiecie lubaczowskim z wiosny 1945 r. Odnosi się to zarówno do spotkań sondażowych na szczeblu lokalnym (druga połowa kwietnia - początek maja 1945 r.), jak i głównych

${ }^{16}$ Autor na kartach swojej książki dokonał takiego zabiegu co najmniej kilkadziesiąt razy.

17 Zob. np. UPA i WiN, s. 19, przyp. 49; s. 66, przyp. 162; s. 427, przyp. 7.

18 Szerzej na ten temat zob. np. M. Zajączkowski, Pod znakiem króla Daniela, s. 63, 225-227, 250-251, 298-299. 
rozmów (21 V 1945). W tomie źródeł opracowanych przez Huka brakuje też informacji i dokumentów kluczowych, chociażby z punktu widzenia strony ukraińskiej, dla zrozumienia wagi opisywanego problemu. $\mathrm{Na}$ przykład rozkazu dowódcy UPA-Zachód (Zachid) Wasyla Sydora „Szełesta” [Vasil' Sidor „Šelest”] z 1 września 1944 r. ${ }^{19}$, w którym wzywał on do wstrzymania masowych akcji antypolskich w Galicji Wschodniej. Ponadto informacji na temat instrukcji Centralnego Kierownictwa (Prowidu) OUN-B z początku lutego $1945 \mathrm{r}^{20} \mathrm{~W}$ końcu instrukcji wydawanych przez Krajowy Prowid (KP) OUN-B w Polsce w okresie 1945-1947 dotyczących kwestii polskiej. Należy wyraźnie podkreślić, że jedną z pierwszych, o ile nie pierwszą z najważniejszych decyzji podjętych po przybyciu do Polski wczesną wiosną 1945 r. przez Jarosława Starucha „Stiaha” [Âroslav Staruh „Stâg”], który został wyznaczony na stanowisko krajowego prowidnyka OUN-B, było zażegnanie konfliktu z podziemiem poakowskim i w ogóle zmiana taktyki wobec Polaków. Do problemu tego odnoszono się w pierwszych instrukcjach KP OUN-B w Polsce z 10 kwietnia $^{21}$ i 10 maja 1945 r. ${ }^{22}$ Niestety próżno ich szukać w książce Huka. Nie zostały w niej zamieszczone także dokumenty AK/DSZ wytworzone chociażby w maju i czerwcu 1945 r., wkrótce po spotkaniach z Ukraińcami w miejscowości Doliny (sprawozdanie z 2 maja i ulotka Ukraińcy z dnia następnego) i przysiółku Żar w powiecie lubaczowskim (protokół z 21 maja czy instrukcja dotycząca m.in. kontaktów z Ukraińcami z 28 czerwca) ${ }^{23}$.

W zamian, obok rozmowy z oficerem podziemia poakowskiego Marianem Gołębiewskim, w książce zostały zamieszczone dokumenty wytworzone przez komunistyczny aparat represji i wojsko. Należą do nich m.in. rozmaite telefonogramy, raporty, sprawozdania czy protokoły

19 Centralne Archiwum Państwowe Najwyższych Organów Władzy i Administracji Ukrainy w Kijowie (dalej: CDAWOWUU), f. 3833, op. 2, t. 3, Rozkaz dowódcy UPA-Zachid Wasyla Sydora „Szełesta” nr 7/44, 1 IX 1944, k. 64-68; G. Motyka, Ukraińska partyzantka, s. 401.

20 G. Motyka, Ukraińska partyzantka, s. 429-430.

${ }^{21}$ T. Bereza, Tragiczne mikrohistorie: Wiazownica, 17 kwietnia 1945 roku, w: Akcja ,Wisła”, red. J. Pisuliński, Warszawa 2003, s. 194.

${ }^{22}$ Archiwum Państwowe w Lublinie (dalej: APL), Ukraińska Powstańcza Armia Zachód VI Okręg Wojskowy (dalej: UPA), 70, Instrukcja Krajowego Prowidu OUN-B w Polsce dotycząca zmiany taktyki wobec Polaków i bolszewików, 10 V 1945, k. 54; G. Motyka, Ukraińskie „powstanie”, „Karta” 1999, 29, s. 62-64.

23 AIPN, 1572/1294, „Sprawozdanie ze zjazdu przedstawicieli UPA z k[omen]d[an] t[em] rej[onu] por. «Małym» w dniu 2 V 1945 r.", b.d., k. 1; ibidem, 1572/1294, Ulotka polskiego podziemia zatytułowana: „Ukraińcy”, 3 V 1945, k. 3; ibidem, 1572/1294, „Protokół ze spotkania władz AK z przedstawicielami ukraińskimi w dniu 21 V 1945 r.", k. 4-6; ibidem, 1572/1294, Instrukcja DSZ dotycząca m.in. kontaktów z Ukraińcami, 28 VI 1945, k. 7. 
przesłuchań w MBP w Warszawie z lat 1946-1948 wspomnianego już Gołębiewskiego, prezesa I Zarządu Głównego WiN płk. Jana Rzepeckiego, prezesa Obszaru Centralnego WiN płk. Józefa Rybickiego oraz członków ścisłego kierownictwa podziemia ukraińskiego w Polsce - dowódcy UPA Myrosława Onyszkewycza [Miroslav Oniškevič] "Oresta” i krajowego referenta Służby Bezpieczeństwa (SB) OUN-B Petra Fedoriwa „Dalnycza” [Petro Fedorìv „Dal'nič”].

W istocie recenzowane opracowanie jest tylko pośrednio przypomnieniem ważnego epizodu w trudnych relacjach polsko-ukraińskich lat czterdziestych ubiegłego stulecia. Wydaje się, że stanowi on w nim raczej pretekst dla złożenia hołdu partyzantom UPA walczącym za „Niezależne Zjednoczone Państwo Ukraińskie” na wszystkich „etnograficznych ziemiach ukraińskich". Poniekąd też członkom bojówek Służby Bezpieczeństwa (BSB) OUN-B, którzy są błędnie określani przez Autora terminem „żołnierze UPA"24. W głównej mierze zaś dla oddania czci wspomnianemu już Sztenderze, który także Hukowi jawi się prawie wyłącznie jako „żołnierz UPA”25. Trudno zgodzić się z tą opinią, wiedząc, że w latach 1943-1944, co wynika m.in. z rozmowy ze Sztenderą opublikowanej na kartach recenzowanej książki, w szeregach UPA odbywał on co najwyżej kolejne kursy szkoleniowe. Począwszy natomiast od czasów junactwa po okres, kiedy piastował w organizacji „odpowiednio wysokie stanowiska", m.in. jako referent SB OUN-B w prowidzie powiatu/nadrejonu jarosławskiego „Baturyn” [„Baturin”], następnie w Okręgu II OUN-B tzw. Kraju Zakerzońskiego (od marca do maja-czerwca 1945 r.) był przede wszystkim członkiem OUN-B ${ }^{26}$. W tym czasie Sztendera posługiwał się pseudonimem „Zorianyj” [„Zorânij”]. Z tego też wynikała bezwzględna podległość jego rozkazom Iwana Szpontaka [Ivan Špontak] „Zalizniaka”, dowódcy UPA na tym terenie. O tym fakcie jednak z pracy Huka nie dowiemy się.

Nawiasem mówiąc, wspomniany termin „żołnierze UPA” jest używany przez Autora na wyrost, gdyż w istocie partyzanci ukraińscy byli jedynie członkami podporządkowanych OUN-B wyspecjalizowanych bojówek, które w zależności od powierzonych zadań przybierały rozmaite formy i nazewnictwo: oddział specjalnego przeznaczenia (widdił osobływoho pryznaczennia [vìddìl osoblivogo priznačennâ], WOP),

${ }^{24}$ UPA $i$ WiN, s. xxxvi. Choć SB OUN-B posiadała pion wojskowy, to była ona przede wszystkim czymś w rodzaju policji politycznej w szeregach banderowskiego podziemia. Organem, który sprawował w praktyce nieograniczony nadzór nad wszystkimi jego komórkami.

${ }^{25}$ Ibidem, s. Xv-xvi.

${ }^{26}$ Ibidem, s. 14-15. 
bojówka administracyjna (AB), kuszczowy oddział samoobrony (samooboronnyj kuszczowyj widdił [samooboronnij kuŝovij vìddil], SKW), czy wspomniane już UPA i BSB. Pod wieloma względami, po stronie polskiej, nasuwa się porównanie jedynie ze wspomnianymi NSZ ZJ, które nie podporządkowując się akcji scaleniowej KG AK, usytuowały się na marginesie polskiej konspiracji niepodległościowej czasu wojny, to znaczy jedynie w roli bojówki partyjnej.

Z niewiadomych powodów Autor spolszcza w książce, w dużym stopniu na siłę, imiona ukraińskie (np. Dymitr zamiast Dmytro [Dmitro], Eugeniusz zamiast Jewhen [Êvgen], Jerzy zamiast Jurij [Ûrìj], Piotr zamiast Petro, Sergiusz zamiast Serhij [Sergì], Włodzimierz zamiast Wołodymyr [Volodimir]; choć nie zawsze konsekwentnie, bo już nie Jan, lecz Iwan [Ivan]). Albo tłumaczy na język polski, bez podania brzmienia oryginalnego, np. kryptonimy oddziałów UPA (np. „Wilki” zamiast „Wowky” [„Vovki”], „Koczownicy” zamiast „Koczowyky” [„Kočoviki”] itp.).

Należy wyraźnie podkreślić, że Huk prezentuje w swojej pracy podwójne standardy. Przykładem tego jest chociażby zestawienie opinii Autora na temat dwóch zbrodni popełnionych na cywilach w powiecie hrubieszowskim dystryktu lubelskiego GG w czasie konfliktu polsko-ukraińskiego w marcu 1944 r. To znaczy mordu dokonanego przez AK na ukraińskich chłopach w Sahryniu (10 marca) i przez UPA na polskich chłopach w Tarnoszynie (z 17 na 18 marca). Według Huka w przypadku Sahrynia mamy do czynienia z ofiarami „mordu masowego” lub „mordu zbiorowego" dokonanego przez $\mathrm{AK}^{27}$. W przypadku zaś Tarnoszyna jedynie z ofiarami „walki [UPA] z oddziałem AK”, która spowodowała „łączne straty wśród polskiej ludności cywilnej wsi i akowców"28. Nawiasem mówiąc, identycznej argumentacji i języka jak Huk w odniesieniu do okoliczności wydarzeń w Tarnoszynie używają przedstawiciele polskich środowisk kresowo-narodowych występujący w roli obrońców „dobrego imienia Rzeczypospolitej Polskiej i Narodu Polskiego" do opisu i oceny wypadków w Sahryniu ${ }^{29}$.

Zdumiewać muszą także rozważania Huka na temat rzekomych rozbieżności między polską i ukraińską historiografią co do wysokości strat poniesionych przez ludność ukraińską z rąk polskiego podziemia w Szychowicach 10 marca 1944 r. Autor stwierdza, że wieś Szychowice to również „miejsce mordu zbiorowego dokonanego przez Armię Krajową 10 marca 1944 r. Ofiarą padło wtedy nie mniej jak 137 osób narodowości

27 Ibidem, s. 34, przyp. 89; s. 80, przyp. 13, 14; s. 535, przyp. 10.

${ }^{28}$ Ibidem, s. 485, przyp. 11.

${ }^{29}$ Zob. np. T. Isakowicz-Zaleski, Sahryń nie był ludobójstwem, „,Gazeta Polska” 3 VIII 2011. 
ukraińskiej”30. Ale już kilkadziesiąt stron dalej czytamy: „10 marca 1944 r. oddziały AK i BCh popełniły mord zbiorowy na cywilnych mieszkańcach Szychowic narodowości ukraińskiej, zabijając nie mniej, jak 176 osób według danych ukraińskich, 137 wg danych polskich"31. Nie wiadomo jednak o jakich danych ukraińskich mówi Huk i skąd wziął tak wysoką liczbę ofiar ukraińskich (176), skoro najnowsze ustalenia Igora Hałagidy, opierające się głównie na źródłach ukraińskich, potwierdzają zabicie 138 mieszkańców Szychowic ${ }^{32}$. Dla Huka liczba 137 ofiar, która została ustalona przez Ukraiński Komitet Pomocy (Ukrajinśkyj dopomohowyj komitet [Ukraïns'kij dopomogovij komitet], UDK) w Hrubieszowie i chełmską OUN-B na początku maja 1944 r., to „dane polskie”. Najwidoczniej Autor przyjął, że szacunki pochodzące ze źródeł proweniencji ukraińskiej, po przywołaniu ich przez przedstawiciela polskiej historiografii, stają się nagle „danymi polskimi” 33 .

Problem ten dotyczy również sposobu prezentowania bilansu ofiar konfliktu polsko-ukraińskiego. Na przykład zwraca uwagę swoiste przywiązanie Autora do wspomnianego sformułowania „nie mniej, jak...” poprzedzającego za każdym razem liczbę ofiar konfliktu narodowościowego w danej miejscowości. Z jedną wszakże istotną różnicą. W przypadku bowiem strat ukraińskich to „nie mniej, jak...” zawsze odnosi się do najwyższej ustalonej przez badaczy liczby ofiar. W przypadku zaś strat polskich Autor ogranicza się jedynie do liczby najniższej. $\mathrm{Na}$ przykład w czasie napadu i spalenia wsi Borodyca (ukr. Bohorodyca) dokonanego z 18 na 19 maja 1945 r. nie - jak twierdzi Huk - przez „oddział UPA" ${ }^{4}$, lecz tzw. oddział specjalnego przeznaczenia podporządkowany SB OUN-B i dowodzony przez Wołodymyra Sywaka [Volodimir Sivak] „Zirkę”, w monografii, z której Huk czerpie na ten temat wiedzę (bez powołania się na jej tytuł i autora) znajdują się informacje o dużo większej liczbie polskich ofiar („repatriantów” z Wołynia). To znaczy nie o ośmiu, lecz w sumie o 36 osobach, z czego 28 uznano za zaginione, gdyż prawdopodobnie spłonęły wraz z zabudowaniami podpalonymi przez ukraińskich partyzantów ${ }^{35}$. Warto dodać, że wspomnianą

30 UPA $i$ WiN, s. 448, przyp. 12.

31 Ibidem, s. 527, przyp. 1.

${ }^{32}$ I. Hałagida, Ukraińskie straty osobowe $w$ dystrykcie lubelskim (październik 1939 - lipiec 1944) - wstępna analiza materiału statystycznego, „Pamięć i Sprawiedliwość” 2017, 1 (29), s. 406.

33 Zob. M. Zajączkowski, Ukraińskie podziemie, s. 302.

${ }^{34}$ UPA $i$ WiN, s. 442, przyp. 1.

${ }^{35}$ Zob. RGWA, f. 38669, op. 1, t. 32, k. 397; M. Zajączkowski, Pod znakiem króla Daniela, s. 147. 
akcję podziemia banderowskiego uznaje się za ostatnią w całym łańcuchu zdarzeń zapoczątkowanych w lutym 1943 r. na Wołyniu i zakończonych w maju 1945 r. na Chełmszczyźnie.

Ponadto Huk z sobie jedynie wiadomych powodów próbuje z zapałem dowieść istniejącej jakoby ciągłości procesu decyzyjnego dotyczącego kwestii ukraińskiej w Polsce przed II wojną światową, w czasie i po jej zakończeniu, stawiając znak równości między władzami II RP i Rządem RP na Uchodźstwie a władzami Polski „lubelskiej”. Dlatego, pisząc np. o zwycięskim starciu w nocy z 5 na 6 maja 1946 r. połączonych oddziałów UPA i bojówek SB OUN-B z jednym z batalionów 5. pp 2. DP, który przesiedlał do USRR ukraińskich mieszkańców wsi Chorobrów w powiecie hrubieszowskim, Huk stosuje kwieciste sformułowanie: „Akcja w Chorobrowie przeciwko członkom aparatu przemocy Rzeczpospolitej Polskiej wyróżniającym się w terroryzowaniu Ukraińców" ${ }^{36}$. W innym miejscu, mając na myśli podobóz ukraiński w Centralnym Obozie Pracy w Jaworznie, używa do jego określenia nie mniej barokowego języka: „polski państwowy obóz koncentracyjny, gdzie w latach 1947-1948 rząd Rzeczpospolitej Polskiej przetrzymywał m.in. kilka tysięcy obywateli polskich narodowości ukraińskiej ujętych w czasie akcji «Wisła»"37.

I jeszcze kilka wybranych przykładów błędów lub nieścisłości, które znajdziemy w opracowaniu:

s. XXVII - za wielce niefortunną należy uznać próbę udowodnienia przez Autora, że UPA i organizowany od wiosny-lata 1943 r. przez OUN-B w Galicji Wschodniej jej odpowiednik pod nazwą Ukraińska Samoobrona Ludowa (Ukrajinśka narodna samoobrona/Ukraïns'ka narodna samoobrona, UNS), to były dwa odrębne byty. Według wykładni Huka UNS, to „inna i utworzona później formacja”. Jego konstatacja wynika niestety z powierzchownej wiedzy na temat dziejów podziemia banderowskiego. Dodatkowo obudowana jest quasi-antropologiczną teorią o chłopskiej armii (UPA) i nacjonalistycznej OUN-B na Wołyniu w 1943 r. oraz inteligenckiej Ukraińskiej Głównej Radzie Wyzwoleńczej (Ukrajinśka Hołowna Wyzwolna Rada/Ukraïns'ka Gołowna Vizvol'na Rada, UHWR) i jakoby nienacjonalistycznej, ludowej samoobronie (UNS) w Galicji Wschodniej w 1944 r. Gwoli wyjaśnienia, w Galicji do końca 1943 r. za przyjęciem innej nazwy niż UPA dla oddziałów zbrojnych OUN-B nie przemawiały bynajmniej różnice natury światopoglądowej czy klasowej między Ukraińcami z Wołynia i Galicji, jak Autor usilnie stara się tego dowieść, lecz inny powód - chęć ukrycia przed władzami niemieckimi faktycznego

36 UPA $i$ WiN, s. 513, przyp. 8.

37 Ibidem, s. 629, przyp. 10. 
charakteru UNS w początkowej fazie jej organizowania i tym samym opóźnienia ewentualnych represji z ich strony ${ }^{38}$;

s. 10, przyp. 18 - sotenny Mykoła Olijnyk „Oreł” [Mikola Olìnnik „Orel”] został skazany przez sąd polowy na karę śmierci i 14 kwietnia $1944 \mathrm{r}$. rozstrzelany nie z powodu „kontaktów z wojskiem niemieckim”, lecz za niewykonanie rozkazu i ukrywanie się na głębokim zapleczu polsko-ukraińskiego frontu w czasie bitwy pod Posadowem 9 kwietnia 1944 r. ${ }^{39}$;

s. 17, przyp. 40 - Wołodymyr Horbowyj „Buwałyj” [Volodimir Gorbovij „Buvalij”] nie mógł brać udziału w rozmowach z AK/DSZ na terenie pow. lubaczowskiego w maju 1945 r., gdyż przybył tam dopiero w połowie czerwca tego roku ${ }^{40}$;

s. 20, przyp. 55 - N.N. „Wadym” [„Vadim”], „Zołotarenko” [,Zolotarenko"], to Stepan Nowyćkyj [Stepan Novic'kij] „Spec"41;

s. 20, przyp. 56 - Jarosław Biłyj „Milko” [Ároslav Bìlij „Mìlko”], „Płastun” [„Plastun”] 27 października 1945 r. nie mógł brać udziału w rozmowach z WiN w Kolonii Tucznej w powiecie bialskim, gdyż 16 października 1945 r. został aresztowany przez włodawski Urząd Bezpieczeństwa w Kolonii Lacku (jako „Siryj” [„Sìrij”], „Sokyra” [,Sokira”]) m.in. razem z prowidnykiem nadrejonu „Łewada” [„Levada”] w Okręgu III OUN-B Jewhenem Skrzynskim „Chmarą” [Êvgen Skžinskij „Hmara”]. We wrześniu 1945 r. Biłyj w korespondencji z WiN używał pseudonimu „Kryha” [„Kriga”]. W rzeczywistości, po jego aresztowaniu zarówno w rozmowach z WiN w Kolonii Tucznej, jak i w późniejszej korespondencji pod pseudonimem „Kryha” występował Serhij Martyniuk „Hrab” [Sergij Martinûk „Grab"] ${ }^{42}$, którego absencję na spotkaniu z Polakami 27 października 1945 r., z powodu co najmniej nieznajomości dokumentów komunistycznego aparatu represji, Huk założył błędnie ${ }^{43}$. Dziwi to tym bardziej, iż w 2005 r. Autor opublikował relację Martyniuka, z której wynikało, że jako „Kryha” brał on udział w rozmowach z przedstawicielami WiN

38 Zob. np. G. Motyka, Ukraińska partyzantka; V. Moroz, Peremys'ka Voênna okruga UPA „Sân” (1944 r.), „Ukraïns'kij vizvolnij ruh. Naukovij zbìrnik” 2012, 17, s. 269-270.

${ }^{39}$ Litopis UPA. Nova serîa, t. 12: Voênna Okruga UPA „Bug”. Dokumenti ì materâli 19431952, Kniga 1, red. V. Moroz, O. Vovk, Kiïv-Toronto 2009, s. 571-572.

${ }^{40}$ M. Zajączkowski, Pod znakiem króla Daniela, s. 224.

${ }^{41}$ I. Hałagida, Prowokacja „Zenona”. Geneza, przebieg i skutki operacji MBP o kryptonimie "C-1" przeciwko banderowskiej frakcji OUN i wywiadowi brytyjskiemu (1950-1954), Warszawa 2005, s. 66, 68-70.

${ }^{42}$ AIPN w Lublinie, 037/6, Akta PUBP we Włodawie, Załącznik do sprawozdania dekadowego Sekcji 2 (Kontrwywiadu) do Wydziału I WUBP w Lublinie, 16 X 1945, k. 73; AIPN, MBP, OUN, IX/40, Sprawozdanie „Skoba” z pobytu na Podlasiu, 13 I 1946, k. 201; M. Zajączkowski, Pod znakiem króla Daniela, s. 234-236.

${ }^{43}$ Zob. także: UPA $i$ WiN, s. 93, 129-139, 175, 180. 
27 października $1945 \mathrm{r} .{ }^{44}$ Ponadto tu i dalej Huk błędnie stosuje termin „referent polityczny” na określenie funkcji kierownika (prowidnyka) na danym szczeblu OUN-B. Należy podkreślić, że w latach 1945-1947 funkcja referenta polityczno-propagandowego lub referenta propagandy, czyli osoby stojącej na czele referatu polityczno-propagandowego w kierownictwie OUN-B danego szczebla, w nomenklaturze organizacji nie była tożsama z funkcją prowidnyka;

s. 34, przyp. 89 - wieś Sahryń w pow. hrubieszowskim nie została zniszczona przez AK 10 marca 1943 r., lecz rok później - 10 marca 1944 r. Wierzę, że to jedynie pomyłka redakcyjna, choć próba dwukrotnego umiejscawiania akcji antyukraińskiej AK w Sahryniu zarówno w marcu 1943, jak i rok później, była podejmowana wcześniej w niektórych opracowaniach ukraińskich ${ }^{45}$;

s. 77, przyp. 6 - w nocy z 26 na 27 maja 1943 r. wieś Strzelce nie została spacyfikowana przez oddziały BCh, lecz przez oddziały Kedywu hrubieszowskiej AK. Nie dokonano wówczas mordu na ukraińskich mieszkańcach bez względu na ich wiek czy płeć, jak zdaje się sugerować Huk, lecz zabijano przeważnie mężczyzn, na co zwracano uwagę także $\mathrm{w}$ dokumentach OUN-B ${ }^{46}$. Wśród 22 zabitych i pięciu rannych mieszkańców wsi były trzy kobiety ${ }^{47}$;

s. 95, przyp. 39 - to nie jacyś enigmatyczni „ukraińscy działacze niepodległościowi", lecz OUN-B Aktem 30 czerwca 1941 r. proklamowała we Lwowie odrodzenie państwa ukraińskiego pod kierownictwem samozwańczego rządu Zachodnich Ziem Ukraińskich (ZUZ) Jarosława Stećki [Âroslav Stec'ko] ${ }^{48}$;

s. 132, przyp. 8 - Wołodymyr Batalija [Volodimir Bataliâ] „Łewko” [„Levko”], „Chmurnyj” [„Hmurnij”], „Zacharczuk” [Zaharčuk”], krypt. „22/Ib”, podreferent spraw polskich $\mathrm{w}$ nadrejonowym referacie SB „Łyman” [„Liman”] w Okręgu III OUN-B nie brał udziału w rozmowach z AK/DSZ (a nie WiN, jak pisze Huk) 21 maja 1945 r. w przysiółku Żar w pobliżu Lublińca Nowego w powiecie lubaczowskim i nie używał

${ }^{44}$ Spomin Sergiâ Martinûka „Graba”, w: Zakerzonnâ. Spomini voâkìv UPA, t. 5, red. B. Huk, Warszawa (Varšava) 2005, s. 206-207.

${ }^{45}$ Por. np. I.K. Patrilâk, M.A. Borowik, Ukraïna v roki Drugoï svitovoï vijni. Sproba novogo konceptual'nogo poglâdu, Kiïv 2010; I.K. Patrilâk, „Vstan'i boris! Sluhaj ì vìr...” Ukraïns'ke nacionalistične pidpillâ ta povstans kij ruh (1939-1960 rr.), L'vìv 2012; idem, „Peremoga abo smert"'. Ukraïns'kij vizvol'nij ruch u 1939-1960 rr., L'vìv 2012.

${ }^{46}$ CDAWOWUU, f. 3833, op. 1, spr. 135, Sprawozdania chełmskiej OUN, Sprawozdanie z Chełmszczyzny i Podlasia, 25 VIII 1943, k. 7.

47 I. Hałagida, Ukraińskie straty, s. 374.

${ }^{48}$ Zob. np. Ukraïnske deržavotvorennâ. Akt 30 czervnâ 1941. Dokumenti ì materìali, red. O. Dzûban, L'vìv-Kyïv 2001. 
pseudonimu „Hrab” w rozmowach z polskim podziemiem. Pseudonimem tym posługiwał się wspomniany już Serhij Martyniuk, jeden z trzech członków ukraińskiej delegacji na tym spotkaniu;

s. 153, przyp. 36 - umowa o wymianie ludności między Polskim Komitetem Wyzwolenia Narodowego a rządem Ukraińskiej Socjalistycznej Republiki Radzieckiej została zawarta nie 1 września 1944 r., lecz 9 września tego roku ${ }^{49}$;

s. 182, przyp. 297 - 21 maja 1945 r. przedstawiciele podziemia banderowskiego nie prowadzili rozmów z przedstawicielami Zrzeszenia WiN, gdyż w tym czasie ono jeszcze nie istniało, lecz z AK/DSZ;

s. 266, przyp. 2 - pseudonim „Petro” nie został przyjęty przez Łeonida Łapinśkiego [Leonìd Lapins'kij] „Zenona” wyłącznie „na okres akcji hrubieszowskiej” (27/28 V 1946). Łapinśkyj używał go w latach 1945-1947 jako okręgowy referent SB w Okręgu III OUN-B;

s. 413 , przyp. 3 - powodem utworzenia Chełmskiego Legionu Samoobrony w Hrubieszowskiem przez tamtejszy Ukraiński Komitet Pomocy w połowie $1942 \mathrm{r}$. za zgodą władz niemieckich był nie tyle rzekomo silny w tym czasie terror AK i BCh wobec miejscowej ludności ukraińskiej, lecz wzmożenie z wiosną 1942 r. działalności przez partyzantkę komunistyczną na wschodnich terenach dystryktu lubelskiego GG oraz szerzący się tam pospolity bandytyzm ${ }^{50}$;

s. 452, przyp. 23 - w nocy z 14 na 15 marca 1944 r. na stacji kolejki wąskotorowej w Gozdowie bojówka chełmskiej OUN-B Pawła Pyłypczuka [Pavlo Pilipčuk] „Karpa” zastrzeliła nie 21 osób narodowości polskiej, lecz w sumie 31 osób, z czego 27 Polaków i czterech Ukraińców ${ }^{51}$;

s. 509, przyp. 3 - popularnej wśród partyzantów ukraińskich nazwy „finka" nie stosowano do określenia pistoletu maszynowego suomi konstrukcji fińskiej, lecz sowieckiego pistoletu maszynowego PPSz, który był jedynie podobny do fińskiego oryginału. Podążając za tokiem myślenia

${ }^{49}$ Zob. np. J. Pisuliński, Przesiedlenie ludności ukraińskiej z Polski do USRR $w$ latach 1944-1947, Rzeszów 2009.

${ }^{50}$ Zob. np. AIPN, GK, 104/284, Dowódca żandarmerii w dystrykcie lubelskim, „Sprawozdanie z operacji przeprowadzonej przez 1. Zmotoryzowany Batalion Żandarmerii w okresie 19-22 VIII 1942 r. na odcinku zabezpieczenia Łęczna", Lublin 23 VIII 1942, k. 12, 14v-15; ibidem, GK, 104/284, Dowódca żandarmerii w dystrykcie lubelskim, „,Sprawozdanie z operacji przeprowadzonej przez 1. Zmotoryzowany Batalion Żandarmerii 19 IX 1942 r. w okolicy Drelowa", Biała Podlaska, 20 IX 1942, k. 70-71; M. Zajączkowski, Ukraińskie podziemie, s. 93-107, 206; I. Hałagida, Ukraińskie straty, s. 367-371.

${ }^{51}$ APL, Ortskommandantur I/524, 23, mf. 113, Dowódca policji porządkowej w dystrykcie lubelskim, Codzienny raport sytuacyjny, Lublin, 16 III 1944, b.pag. Zob. także: Spomin İwana Nowosada „Stec'ka”, w: Zakerzonnâ. Spohadi voâkìv Ukraïns'koï Povstans'koï Armï̈, oprac. B. Huk, t. 1, Warszawa (Varšava) 1994, s. 199; G. Motyka, Tak było w Bieszczadach, s. 193. 
Autora, zmuszeni bylibyśmy przyjąć, że większość partyzantów ukraińskich w latach 1945-1947 posługiwała się bronią produkcji fińskiej, a nie sowieckiej. Co jest oczywistym nonsensem;

s. 577, przyp. 13 - Ukraiński Komitet Centralny nie powstał jesienią 1939 r., lecz w połowie $1940 \mathrm{r}^{52}$

Błędów lub nieścisłości w książce Huka jest więcej. Niemniej z powodu ograniczonej objętości artykułu recenzyjnego odniosłem się jedynie do niektórych (ważniejszych).

Podsumowując, wypada jedynie żałować, iż Autor, podejmując temat porozumień między podziemiem poakowskim i banderowskim w latach 1945-1947, nie wyzbył się swojej dotychczasowej maniery publicystycznej. Uniemożliwiło mu to dokonanie chłodnej, wnikliwej analizy dostępnego materiału źródłowego, również ukraińskiej proweniencji. Zamiast konstruować teorie i interpretacje oderwane od realiów stosunków polsko-ukraińskich w latach czterdziestych XX w., będące jedynie jego o nich wyobrażeniem, Huk, oprócz przeprowadzenia szerszych kwerend bibliotecznych i archiwalnych, powinien także przykładać należytą staranność do krytyki źródeł oraz wyrażać zdecydowanie więcej pokory wobec faktów. Bez wątpienia przyniosłoby to wymierną korzyść zarówno dla wspomnianej pracy, jak i jej czytelników.

W tym kontekście znamienne są ostatnie zdania ze wstępu recenzowanej książki: „Wychowani dziś na propagandzie nacjonalistycznej po obu stronach granicy, jesteśmy bezradni wobec stwierdzenia, że starcie z RP o wolność Ukrainy nigdy nie przesłoniło kierownictwu OUN i UGWR [winno być: UHWR - M.Z.] swego sensu najgłębszego: walka toczy się o sojusz, a nie zniszczenie" ${ }^{3}$. Autor zdaje się nie dostrzegł, iż tezami głoszonymi na kartach recenzowanej książki wpisuje się w budzącą liczne kontrowersje narrację charakterystyczną dla apologetów banderowskiego podziemia, którą w dodatku propaguje pod pretekstem upowszechniania nieantagonistycznego tematu polsko-ukraińskich porozumień.

Niestety narracja ta ma niewiele wspólnego z rzetelnym ujęciem problemu i solidnym warsztatem historyka lub - jak w przypadku Bogdana Huka - popularyzatora dziejów najnowszych. W związku z powyższym raczej trudno ją uznać za liczący się głos w debacie publicznej dotyczącej polityki wobec pamięci o reżimach totalitarnych w minionym stuleciu, toczącej się w Polsce i Ukrainie.

${ }^{52}$ Zob. np. V. Kubìjovicz, Ukraïncì v General'nìj Guberniï 1939-1941. Istoriâ Ukraïns kogo Central'nogo Komitetu, Čìkago 1975; R. Torzecki, Polacy i Ukraińcy. Sprawa ukraińska w czasie II wojny światowej na terenie II Rzeczypospolitej, Warszawa 1993.

${ }^{53}$ UPA $i$ WiN, s. xxxiii. 


\section{Streszczenie}

Niniejszy tekst jest krytycznym podejściem do wydanej przez Bogdana Huka książki dotyczącej współpracy między podziemiem polskim (poakowskim) i ukraińskim (banderowskim) na wschodniej Lubelszczyźnie w latach 1945-1947 (UPA i WiN $w$ walce $z$ totalitaryzmem 1945-1947. Dokumenty. Wspomnienia, Przemyśl 2018). Składa się na nią zbiór wspomnień, w znakomitej większości ukraińskiej proweniencji, oraz dokumentów wytworzonych głównie przez komunistyczny aparat represji i wojsko Polski „lubelskiej”, jak również struktury podziemia ukraińskiego. W zbiorze tym nie znajdziemy jednak dokumentów polskiego podziemia. Wbrew tytułowi sugerującemu szerokie ujęcie problemu, Huk przesuwa środek ciężkości w zasadzie na jeden epizod polsko-ukraińskiego porozumienia - wspólną akcję zbrojną UPA i WiN w Hrubieszowie w maju 1946 r. Niestety, w recenzowanej pracy zabrakło podstawowych informacji oraz istotnych dokumentów, tak polskich, jak i ukraińskich, które odnoszą się do całości bardzo interesującego i jednocześnie złożonego problemu odchodzenia od konfliktu i dochodzenia do porozumienia i współpracy między AK/DSZ i WiN a OUN-B i UPA na północno-wschodnich terenach Rzeszowszczyzny i południowo-wschodniej Lubelszczyźnie, gdzie w końcowym okresie okupacji niemieckiej (jesień 1943 - wiosna 1944 r.) doszło do najkrwawszej odsłony konfliktu narodowościowego, biorąc pod uwagę ziemie dzisiejszej Polski. W niniejszym artykule recenzyjnym zostały wskazane jedynie ważniejsze błędy rzeczowe widniejące w książce. Krytyce poddane zostały również tezy zawarte w jej wstępie oraz część informacji znajdujących się w aparacie naukowym, którym zostały opatrzone źródła. Ilustrują one bowiem jedynie wyobrażenia Autora na temat relacji polsko-ukraińskich w czasie II wojny światowej i we wczesnych latach powojennych, w dużym stopniu odległe od prawdy historycznej i niezwiązane z zasadniczym tematem pracy.

\section{Reinventing the Wheel? Bogdan Huk's Reflections on Joint Polish-Ukrainian Fight against Communist Regime in Lublin Poland}

The present text is a critical review of the book published in 2018 on the collaboration between the Polish underground (post-Home Army) and Ukrainian one (Banderite) in the eastern Lublin Region in 1945-1947 (UPA $i$ WiN w walce $z$ totalitaryzmem 1945-1947. Dokumenty. Wspomnienia [The Ukrainian Insurgent Army and Freedom and Independence Organisation in the Fight against Totalitarianism 1945-1947. Documents. Reminiscences]). It is a collection of memories, in the vast majority of Ukrainian provenance, and documents generated mainly by the communist apparatus of repression and the army of "Lublin's" Poland and the structures of the Ukrainian underground. In the collection, however, there are no documents of the Polish underground.

Contrary to the title suggesting a broad approach to the subject, the Author places the centre of gravity basically on one episode of the Polish-Ukrainian agreement: a joint military action of the Ukrainian Insurgent Army and the Freedom 
and Independence (WiN) at the village of Hrubieszów in May 1946. Unfortunately, the reviewed book lacks the fundamental information and relevant documents, both Polish and Ukrainian ones, related to the interesting and complex problem of departing from conflict and coming to agreement and collaboration between the Home Army/Armed Forces Delegation for Poland (AK/DSZ) and Freedom and Independence on the one side, and Organization of Ukrainian Nationalists-Banderites and the Ukrainian Insurgent Army (OUN-B and UPA) in the north-eastern territories of the Rzeszów Region and the south-eastern Lublin Region. It was there that at the end of the German occupation (autumn 1943 - spring 1944) the bloodiest act of the nationality conflict (as regards the territory of today's Poland) took place.

The present review article indicates only more severe factual errors made in the book. It also criticises the theses put forward by its Author in the introduction to the book as well as some information included in the scholarly apparatus to the sources; they only illustrate what the Author believed to be true of the Polish-Ukrainian relations during the Second World War and first years after the war, very far from the historical truth and unrelated to the main subject of the book.

Translated by Grażyna Waluga

\section{Bibliografia}

Bereza Tomasz, Tragiczne mikrohistorie: Wiazownica, 17 kwietnia 1945 roku, w: Akcja „Wisła”, red. Jan Pisuliński, IPN, Warszawa 2003, s. 187-194.

Dudek Justyna, Marian Gołębiewski (1911-1996) - żołnierz, opozycjonista, emigrant, IPN - KŚZpNP, Lublin 2016.

Hałagida Igor, Prowokacja „Zenona”. Geneza, przebieg i skutki operacji MBP o kryptonimie „C-1" przeciwko banderowskiej frakcji OUN i wywiadowi brytyjskiemu (1950-1954), IPN - KŚZpNP, Warszawa 2005.

Hałagida Igor, Ukraińskie straty osobowe $w$ dystrykcie lubelskim (październik 1939 - lipiec 1944) - wstępna analiza materiału statystycznego, „Pamięć i Sprawiedliwość” 2017, 1 (29), s. 353-412.

Isakowicz-Zaleski Tadeusz, Sahryń nie był ludobójstwem, „Gazeta Polska” 3 VIII 2011. Kopiński Jarosław, Relacje WiN-UPA w Inspektoracie WiN Biała Podlaska w latach 19451947, „Zeszyty Historyczne WiN-u” 1996, 9, s. 85-90.

Kubìjovič Volodimir, Ukraïncì v General'nì Guberniï 1939-1941. Istoriâ Ukraïns'kogo Central'nogo Komitetu, Vidavnictvo Mikoli Denisûka, Čìkago 1975.

Litopis UPA, t. 39: Taktičnij vidtinok UPA 28-j „Daniliv”: Cholmŝina ì Pidlâššâa (Dokumenti ì materâli), red. Petro Potǐčnij, Vidavnictvo „Lìtopis UPA”, Toronto-L'vìv 2003. Litopis UPA. Nova serîâ, t. 12: Voênna Okruga UPA „Bug”. Dokumenti ì materâli 1943-1952, Kniga 1, red. Volodimir Moroz, Oleksandr Vovk, Vidavnictvo „Litopis UPA”, Kiïv-Toronto 2009.

Moroz Volodimir, Peremys'ka Voênna okruga UPA „Sân” (1944 r.), „Ukraïns'kij vizvolnij ruch. Naukovij zbìrnik" 2012, 17, s. 259-335.

Moszkowicz Mariusz, Gdzie w maju 1945 r. kierownictwo Inspektoratu AK-DSZ Zamość prowadziło rozmowy $i$ zawarło porozumienie z OUN-B $i$ UPA?, „Cieszanowskie Zeszyty Regionalne" 2012, 5, s. 71-84. 
Motyka Grzegorz, Tak było w Bieszczadach. Walki polsko-ukraińskie 1943-1948, Volumen, Warszawa 1999.

Motyka Grzegorz, Ukraińska partyzantka 1942-1960. Działalność Organizacji Ukraińskich Nacjonalistów i Ukraińskiej Powstańczej Armii, ISP PAN, Rytm, Warszawa 2006.

Motyka Grzegorz, Ukraińskie „powstanie”, „Karta” 1999, 29, s. 62-64.

Motyka Grzegorz, Wnuk Rafał, Pany i rezuny. Współpraca AK-WiN i UPA 1945-1947, Volumen, Warszawa 1997.

Ostasz Grzegorz, Nad protokołem rozmów WiN-UPA z 18 maja 1946 roku, „Zeszyty Historyczne WiN-u" 2000, 14, s. 159-164.

Patrilâk Ivan K., „Peremoga abo smert”. Ukraïns'kij vizvol'nij ruch u 1939-1960 rr., Časopis, L'vìv 2012.

Patrilâk Ivan K., „Vstan' ì boris'! Sluhaj ì vìr..." Ukraïns'ke nacionalìstične pidpillâ ta povstans'kij ruch (1939-1960 rr.), Časopis, L'vìv 2012.

Patrilâk Ivan K., Borowik Mikoła A., Ukraïna v roki Drugoï svitovoï vijni. Sproba novogo konceptual'nogo poglâdu, Kiïv 2010.

Pisuliński Jan, Przesiedlenie ludności ukraińskiej z Polski do USRR w latach 1944-1947, Wydawnictwo Uniwersytetu Rzeszowskiego, Rzeszów 2009.

Spomin İwana Novosada „Stec ka”, w: Zakerzonnâ. Spohadi voâkìv Ukraïnskoï Povstans'koï Armiï, t. 1, oprac. Bogdan Huk, Archiwum Ukraińskie (Ukraïns'kij arhìv), Warszawa (Varšava) 1994.

Spomin Sergiâ Martinûka „Graba”, w: Zakerzonnâ. Spomini voâkìv UPA, t. 5, red. Bogdan Huk, „Tyrsa” (Vidavnictvo „Tirsa”), Warszawa (Varšava) 2005.

Torzecki Ryszard, Polacy i Ukraińcy. Sprawa ukraińska w czasie II wojny światowej na terenie II Rzeczypospolitej, PWN, Warszawa 1993.

Ukraïns ke deržavotvorennâ. Akt 30 czervnâ 1941. Dokumenti ì materiali, red. Orest Dzûban, Lìteraturna agencîâ „Pìramìda” L'vìv-Kyïv 2001.

UPA $i$ WiN $w$ walce z totalitaryzmem 1945-1947. Dokumenty. Wspomnienia, red. Bogdan Huk, Stowarzyszenie Ukraińskie Dziedzictwo, Przemyśl 2018.

Wnuk Rafał, Lubelski Okręg AK DSZ i WiN 1944-1947, Volumen, Warszawa 2000.

Za to że jesteś Ukraińcem... Wspomnienia z lat 1944-1947, oprac. Bogdan Huk, Stowarzyszenie Ukraińców Więźniów Politycznych i Represjonowanych w Polsce, Koszalin-Warszawa-Przemyśl 2012.

Zaborski Marcin, Okręg Lubelski Narodowych Sił Zbrojnych 1942-1944, w: Narodowe Sity Zbrojne. Materiały z sesji naukowej poświęconej historii Narodowych Sił Zbrojnych, Warszawa 25 października 1992 roku, [red. Piotr Szucki], Związek Żołnierzy Narodowych Sił Zbrojnych, Warszawa 1994, s. 179-237.

Zajączkowski Mariusz, Drogi do porozumienia między polskim i ukraińskim podziemiem niepodległościowym w latach 1945-1947, w: Od zniewolenia do wolności. Studia historyczne, red. Adam F. Baran, ISP PAN, Collegium Civitas, Polskie Radio Białystok, Warszawa-Białystok 2009.

Zajączkowski Mariusz, Pod znakiem króla Daniela. OUN-B i UPA na Lubelszczyźnie 19441950, IPN - KŚZpNP, ISP PAN, Lublin-Warszawa 2016.

Zajączkowski Mariusz, Ukraińskie podziemie na Lubelszczyźnie w okresie okupacji niemieckiej 1939-1944, IPN - KŚZpNP, ISP PAN, Lublin-Warszawa 2015. 
Biogram: Mariusz Zajączkowski - dr, historyk i politolog, adiunkt w Instytucie Studiów Politycznych PAN w Warszawie, pracownik w Oddziałowym Biurze Badań Historycznych IPN w Lublinie. Zajmuje się stosunkami polsko-ukraińskimi w latach 1939-1947 oraz dziejami podziemia ukraińskiego (OUN-B i UPA) w okresie II wojny światowej i we wczesnych latach powojennych. Członek powstałego w 2015 r. Polsko-Ukraińskiego Forum Historyków; kontakt: m.zajaczkowski@isppan.waw.pl. 